\title{
Research Regarding the Soil Characteristics and their Influence on Forest Productivity in the Mociar Forest, Mureş County
}

\author{
Marcel MÎNDRU ${ }^{1}$, Ioan PĂCURAR ${ }^{1 *}$, Sanda ROȘCA ${ }^{2}$, Ștefan BILAȘCO ${ }^{2,3}$ \\ Horea PĂCURAR ${ }^{1}$
}

${ }^{1}$ Department of Soil Sciences and Technical Sciences, University of Agricultural Sciences and Veterinary Medicine, 3-5, Mănăştur Street, 400372, Cluj-Napoca, Romania.

${ }^{2}$ Department of Physical and Technical Geography,Faculty of Geography, Babeş Bolyai University, 5-7

Clinicilor St, 400006 Cluj-Napoca Romania.

${ }^{3}$ Romanian Academy Cluj Napoca Subsidiary, Geography Section, 42 A. Treboianu St. Cluj-Napoca

Romania

*Corresponding author, e-mail: ioanpacurarcj@yahoo.com

Bulletin UASVM Horticulture 74(2)/ 2017

Print ISSN 1843-5254, Electronic ISSN 1843-5394

DOI:10.15835/buasvmcn-hort: 0019

\begin{abstract}
The Mociar Forest Reserve has a great scientific interest due to the age of the oaks ranging from 400-500 years, which is why it is included in the protected area category. Over time, a series of studies have been carried out on the occurrence of the oak drying phenomenon in the Mociar Forest in order to develop plans for measures to prevent and combat oak drying. The main reason for this was to analyze the physical and chemical properties of soils. Considering the direct influence of soil characteristics on the development of forest species within the Mociar Forest, we proposed the creation of nine soil profiles located in areas considered representative of the studied area and the identification of the main physical and chemical parameters in the laboratory stage (the soil $\mathrm{pH}$, the nitrogen amount, the total humus and C:N ratio variation). According to the four factors analysed a GIS spatial analysis model has been developed in order to identify the favourability and soil restriction for forest species in the studied area. It was also sought to obtain an overall picture of the distribution of these parameters on their qualitative classes as well as on the distribution classes of specific, dominant forest species. This was made possible by the use of G.I.S. technology and specific geospatial interpolation and spatial analysis tools.
\end{abstract}

Keywords: G.I.S. spatial analysis, interpolation, Mociar Forest, Soil characteristics

\section{INTRODUCTION}

The specialty studies concerning the habitats of community interest included in LIFE05 NAT/ RO/000176 project "Alpine, Subalpine and Forestry Priority Habitat in Romania" focus on forest habitats and on elements constituting potential threats to these habitats.

From the category of community interest habitats that are signalled in the Natura 2000 Mociar site form, it is pointed out at the level of the studied territory: $91 Y 0$ - oak and hornbeam Dacic forests with representative species of Carpinus betulus and various Quercus species (robur, petraea, cerris, frainetto etc.), Tilia tomentosa, Cortinus coggygria, Festuca heterophylla, Ranunculus auricomus, Helleborus odorus etc., as well as Galio-Carpinetum hornbeam-oak forests (9170), Euro-Siberian silvostepa vegetation with Quercus spp (91I0).

Soil, due to its physical and chemical characteristics, influences the existence and development of forest species, being able to form, in case of exceeding threshold values, restrictive or limiting factors, both singularly and in relation to the 


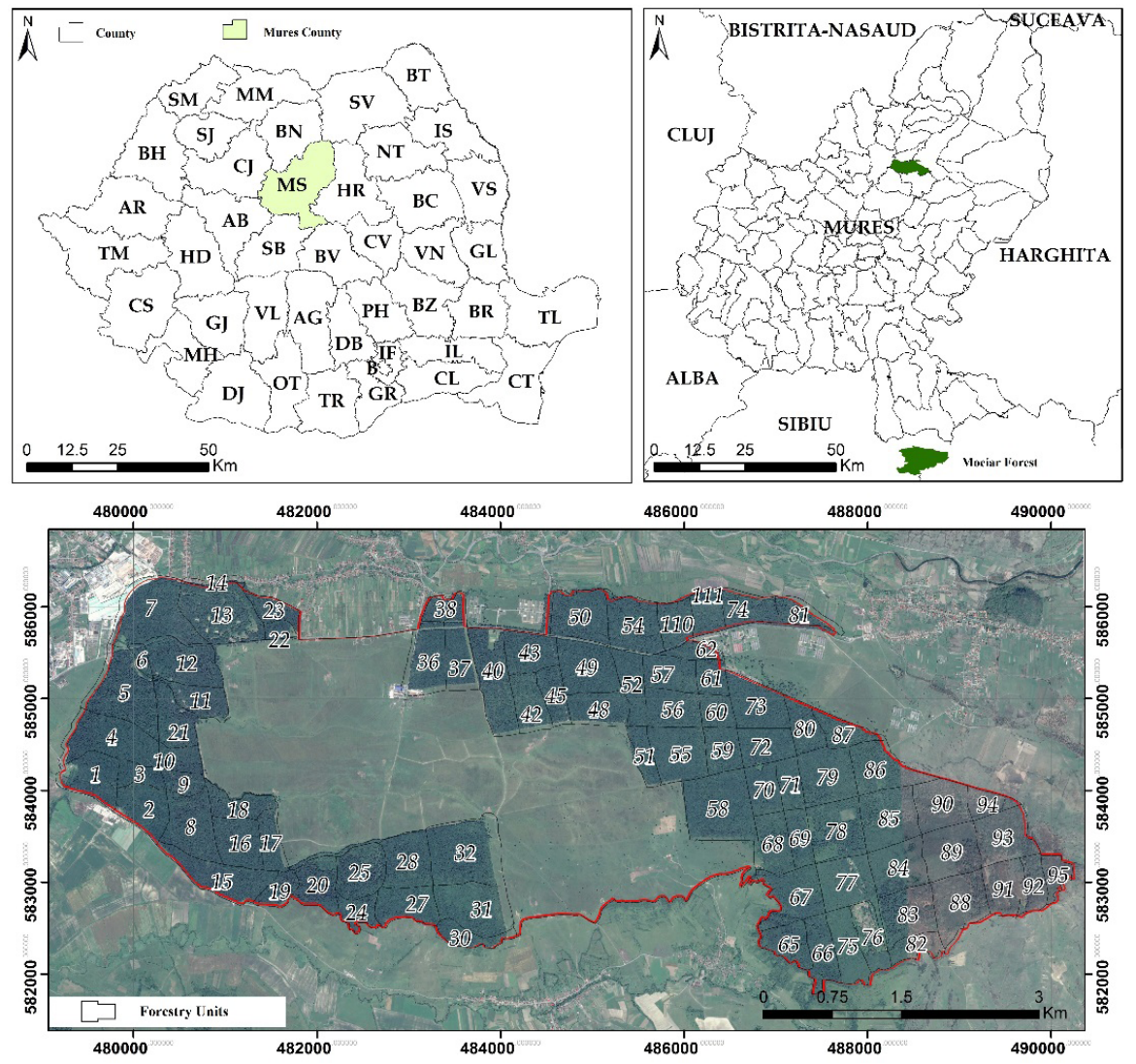

Fig. 1. Geographic site of Mociar Forest (basemap: Google Earth, 2017)

climatic factors (rainfall and temperature) (Florea, 1965; Chiriță, 1967; Asvadurov, 1969; Lupascu and Rusu, 1975; Roşu et al., 1982; Ianos, 1999; Bălăceanu, 2002; Florea and Munteanu, 2003; Păcurar, 2005, 2006).

The knowledge of these limiting factors becomes very important for maintaining biodiversity and favorable conservation status for species and habitats of community interest (Stăncioiu et al., 2007), as well as on the regeneration and restoration of species having intense drying phenomena (Bălănică et al., 1954). The first steps for the protection of forest ecosystems on the Gurghiu Valley coincided with the establishment of the Commission for Natural Monuments promulgated by the Royal Decree no. 148 on the $7^{\text {th }}$ of July 1930 .

There is little data on the vegetation of the Mociar Forest, the researches aimed at this area have integrated the studies for the entire territory of the Gurghiu Valley or the Depression of Transylvania (Paşcovschi, 1937; Paşcovschi, 1942; Emerich and Fuss, 1866; Roșu et al., 1982; Gherghel, 1983; Sânmărghitan, 2005, etc.).
The Mociar Forest belongs to the Gurghiu Forestry Administration, the Inspectorate of Mureş County having a total area of production unit (U.P.) of 2318.1 ha. From a hypsometric point of view, the Mociar forest extends to a $259 \mathrm{~m}$ altitude difference in the range of 363-622 (Fig. 1 ), corresponding to $87.8 \%$ of the low and middle hills area, the remaining 366 hectares $12.2 \%$ ), located in the south-western part of the analyzed area, being classified of the class of high hills characterized by altitudes in the range of 500-622 $\mathrm{m}$.

Our main purpose of the study was to identify the favorability and soil restriction for forest species in the studied area using G.I.S. tools starting from the physico-chemical characteristics of soils identified after the soil field profiles and the laboratory analysis performed.

\section{MATERIALS AND METHODS}

The analysis of the soil characteristics in the analyzed area, Mociar Forest, was carried out following the instructions issued by I.C.P.A., 1987, based on nine profiles located in representative 


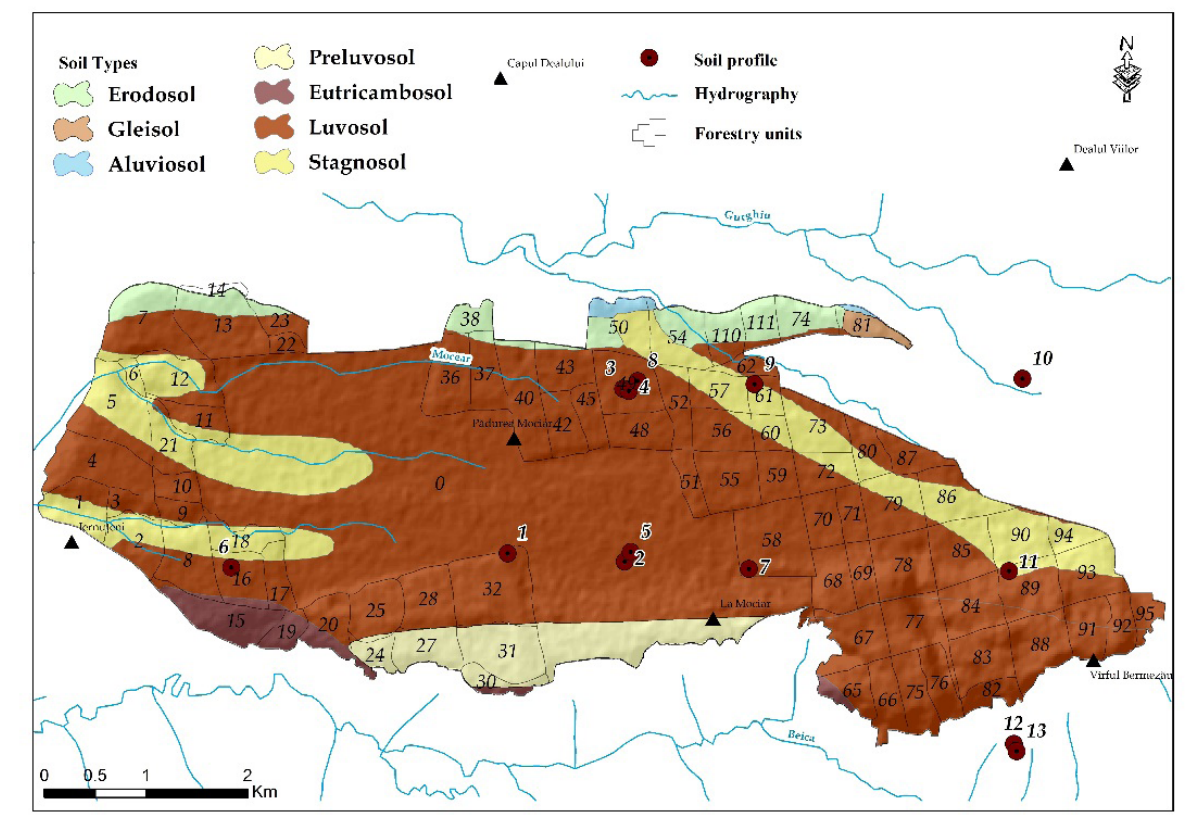

Fig. 2. Map of Soil Types (according to Soil Mapping, 1960) with spatial location of soil profiles

Tab. 1. Spatial distribution of soil types within the Mociar forest

\begin{tabular}{ccc}
\hline Soil type & $\mathrm{m} 2$ & $\%$ \\
\hline Erodosoil & 1256087 & 4.17 \\
\hline Gleisoil & 111055 & 0.37 \\
\hline Aluviosoils & 115793 & 0.38 \\
\hline Preluvosoil & 1497864 & 4.98 \\
\hline Eutricambosoil & 668678 & 2.22 \\
\hline Luvosol typical/albic & 21792497 & 72.39 \\
\hline Stagnosoil & 4661925 & 15.49 \\
\hline
\end{tabular}

places of the research area, so that representative soil types and characteristic subtypes could be captured. For each soil profile the samples were collected on pedogenetic horizons, both in the natural (unmodified) and in the modified settlement, for the profiles (Fig. 2).

Obtaining values of soil characteristics by extrapolating the point values identified in the soil profile was based on the interpolation of intermediate samples through spatial interpolation functions.

One of the main issues to be taken into account in the interpolation process is data representativeness and spatial layout of interpolated values. Thus, the spatial positioning of the nine profiles inside the studied area was analyzed, making three more profiles outside the study area in order to better control the eastern part of the studied area and at the same time to obtain a dispersion coefficient that results in an interpolation of the values with a square quadratic error that validates the performed interpolation.

Preliminary analysis of the edaphic cover of the Mociar forest area on the basis of the Romanian soil map, scale 1: 200000, highlights the very large extent of approximately $72 \%$ of the analyzed area of typical /albic luvosol, a type of soil occurring in the territories benefiting of a quantity of precipitation ranging from 700-1000 $\mathrm{mm} /$ year and an annual average temperature in the range of $6-10^{\circ} \mathrm{C}$.

This type of soil has an aridity index in the range 35-55, indicating a high degree of soil moisture as well as a percolative water regime, 
Tab. 2. Characteristics of Mociar Forest soil

\begin{tabular}{|c|c|c|c|c|c|c|c|}
\hline \multirow[t]{2}{*}{ Profile No. } & & \multicolumn{6}{|c|}{ Genetic marks } \\
\hline & & AoW & EaW & EBW & BtW & BtW & $\mathrm{C}$ \\
\hline \multirow{5}{*}{1} & Depth $(\mathrm{cm})$ & $0-7$ & $10-20$ & $25-35$ & $65-75$ & - & - \\
\hline & Total Humus (\%) & 6.04 & 3.20 & 1.80 & 1.49 & - & - \\
\hline & Total azote (\%) & 0,28 & - & - & - & - & - \\
\hline & $\mathrm{C}: \mathrm{N}$ & 12,5 & - & - & - & - & - \\
\hline & $\mathrm{pH}\left(\mathrm{H}_{2} \mathrm{O}\right)$ & 4.55 & 4.70 & 5.10 & 5.25 & - & - \\
\hline \multirow{5}{*}{2} & Depth $(\mathrm{cm})$ & $0-10$ & $15-25$ & $45-55$ & $80-90$ & - & - \\
\hline & Total Humus (\%) & 4.49 & 2.49 & 0.42 & 0.35 & - & - \\
\hline & Total azote (\%) & 0.190 & - & - & - & - & - \\
\hline & C:N & 13.88 & - & - & - & - & - \\
\hline & $\mathrm{pH}\left(\mathrm{H}_{2} \mathrm{O}\right)$ & 5.08 & 5.15 & 5.60 & 6.20 & - & - \\
\hline \multirow{5}{*}{3} & Depth $(\mathrm{cm})$ & $0-8$ & $15-25$ & $35-45$ & $70-80$ & $100-110$ & $130-140$ \\
\hline & Total Humus (\%) & 8.34 & 5.25 & 0.60 & 1.69 & 1.26 & 1.34 \\
\hline & Total azote (\%) & 0.400 & - & - & - & - & - \\
\hline & $\mathrm{C}: \mathrm{N}$ & 12.07 & - & - & - & - & - \\
\hline & $\mathrm{pH}\left(\mathrm{H}_{2} \mathrm{O}\right)$ & 4.60 & 4.40 & 5.10 & 5.15 & 5.80 & 6.20 \\
\hline \multirow{5}{*}{4} & Depth $(\mathrm{cm})$ & $0-8$ & 8-18 & $18-30$ & $35-45$ & $60-70$ & $100-110$ \\
\hline & Total Humus (\%) & 7.03 & 3.74 & 2.50 & 1.25 & 0.84 & 0.44 \\
\hline & Total azote (\%) & 0.300 & - & - & - & - & - \\
\hline & $\mathrm{C}: \mathrm{N}$ & 13.56 & - & - & - & - & - \\
\hline & $\mathrm{pH}\left(\mathrm{H}_{2} \mathrm{O}\right)$ & 5.15 & 5.30 & 5.10 & 5.20 & 5.55 & 5.95 \\
\hline \multirow{5}{*}{5} & Depth $(\mathrm{cm})$ & $0-8$ & $8-17$ & $25-35$ & $50-60$ & $75-85$ & - \\
\hline & Total Humus (\%) & 5.36 & 3.86 & 2.14 & 0.97 & 0.41 & - \\
\hline & Total azote (\%) & 0.226 & 0.170 & - & - & - & - \\
\hline & $\mathrm{C}: \mathrm{N}$ & 13.71 & 13.11 & - & - & - & - \\
\hline & $\mathrm{pH}\left(\mathrm{H}_{2} \mathrm{O}\right)$ & 5.25 & 5.60 & 5.25 & 5.45 & 5.70 & - \\
\hline \multirow{5}{*}{6} & Depth $(\mathrm{cm})$ & $0-10$ & $16-25$ & $40-50$ & $65-75$ & - & - \\
\hline & Total Humus (\%) & 5.71 & 3.33 & 1.62 & 1.28 & - & - \\
\hline & Total azote (\%) & 0.280 & - & - & - & - & - \\
\hline & C:N & 13.89 & - & - & - & - & - \\
\hline & $\mathrm{pH}\left(\mathrm{H}_{2} \mathrm{O}\right)$ & 4.90 & 4.75 & 5.40 & 5.35 & - & - \\
\hline \multirow{5}{*}{7} & Depth $(\mathrm{cm})$ & $1.5-0$ & $0-10$ & $12-18$ & $25-35$ & $40-50$ & $55-65$ \\
\hline & Total Humus (\%) & 19.74 & 8.33 & 3.45 & 1.63 & 1.85 & 1.48 \\
\hline & Total azote (\%) & 0.770 & - & - & - & - & - \\
\hline & $\mathrm{C}: \mathrm{N}$ & 14.85 & - & - & - & - & - \\
\hline & $\mathrm{pH}\left(\mathrm{H}_{2} \mathrm{O}\right)$ & 4.40 & 4.70 & 4.95 & 5.20 & 5.30 & 5.80 \\
\hline \multirow{5}{*}{8} & Depth $(\mathrm{cm})$ & $0-20$ & $20-40$ & $55-65$ & $75-81$ & - & - \\
\hline & Total Humus (\%) & 6.75 & 4.05 & 3.14 & 1.51 & - & - \\
\hline & Total azote (\%) & 0.310 & - & - & - & - & - \\
\hline & $\mathrm{C}: \mathrm{N}$ & 12.61 & - & - & - & - & - \\
\hline & $\mathrm{pH}\left(\mathrm{H}_{2} \mathrm{O}\right)$ & 5.50 & 5.45 & 5.90 & 6.20 & - & - \\
\hline \multirow{5}{*}{9} & Depth $(\mathrm{cm})$ & $0-10$ & $10-20$ & $35-45$ & $55-65$ & - & - \\
\hline & Total Humus (\%) & 5.69 & 3.72 & 0.40 & 0.89 & - & - \\
\hline & Total azote (\%) & 0.330 & - & - & - & - & - \\
\hline & C:N & - & - & - & - & - & - \\
\hline & $\mathrm{pH}\left(\mathrm{H}_{2} \mathrm{O}\right)$ & 5.10 & 5.25 & 5.65 & 5.75 & - & - \\
\hline
\end{tabular}




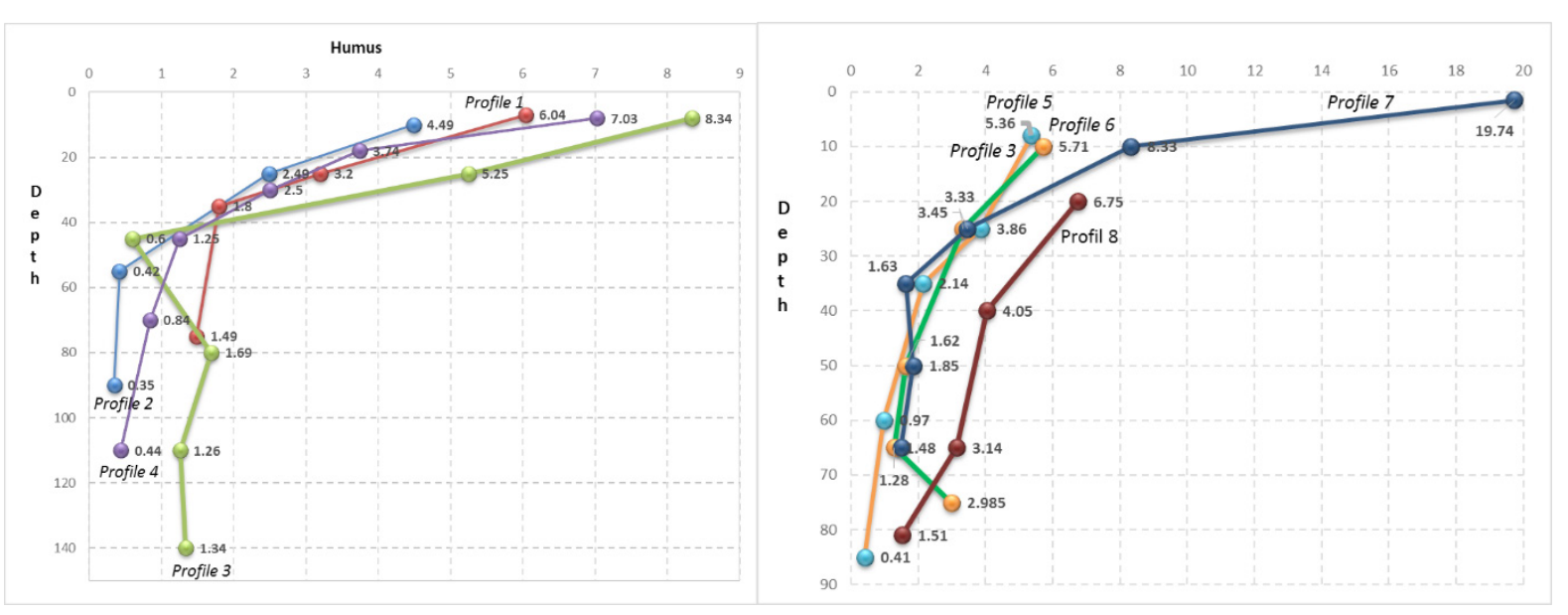

Fig. 3. Difference in humus content for profiles 1-4 (left) and 4-8 (right)

conditions leading to the occurrence of altering and claying phenomena of the mineral material (Grigoraş et al. 2006).

In the conditions of rich precipitation and in the situation where these types of soil develop litter, the soil becomes very acidic. Acidity comes from the penetration of hydrogen ion in the adsorbent complex, replacing the $\mathrm{Ca}++$ and $\mathrm{Mg}++$ ions, favoring the shift of the colloidal clay towards the lower part of the soil profile (Pocovâț, 1935; Cernescu, 1945).

As a result of the realization of the soil profiles, during the field phase, the physicochemical characteristics for each profile were identified, taking into account the methodologies and procedures, and in the office phase these are to be analyzed correlatively and comparatively in order to reveal positive and negative influences on the Mociar Forest's arbustive and vegetation layer.

The granulometric analysis was carried out using the Kacinski method and the soil $\mathrm{pH}$ was determined by the potentiometric method; Total nitrogen $(\mathrm{N})$ was identified by the Kjeldalh method; Accessible (mobile) phosphorus and accessible potassium was determined by the Egner-RiehmDomingo method (Table 2).

It is known that luvosols, which predominate in the analyzed territory due to their specific physical and hydrophobic properties, are less favorable to plant growth (Grigoraş et al., 2006), precipitation water infiltrates hard, stagnating at the top of the profiles, so the phenomenon of stagnogleyzation appears.

The humus content is relatively low in the case of the first four profiles, the maximum being only 8 units, the maximum being reached within the AoW horizon of the profile 7 with identified values of 19.74 (Fig. 3).

In order to increase the applicability of the results thus obtained, the G.I.S. spatial analysis technique was used in order to interpolate the spot results determined in the field and to obtain the grids physic-chemical and hydro-physical indices of the soil in the Mociar Forest area.

The GIS techniques have been used successfully in pedological studies similar to the representative areas (De Veaux et al., 1993; Moore et al., 1993; Bui et al., 1995; Iverrson et al., 1997; Ollingen et al., 1998; Zhu et al., 2001; Zhang and McGrath, 2004; Li et al., 2004; Muñoz and Felicísimo, 2004; Campbell et al., 2008; Gutiérrez et al., 2011; El Jamassi, 2013), as well as studies on agricultural and forest productivity (Roșca, 2015; Roșca et al., 2015), the main purpose of which is to issue monitoring solutions (Smigal et al., 2015; Torresan et al., 2016; Anil et al., 2017), and streamlining the production process.

\section{RESULTS AND DISCUSSIONS}

Combining the traditional methods of punctual identification of soil characteristics with modern techniques of cartographic analysis and mapping, spatial correlations have been obtained between the soil characteristics and representative forest species on the monitored forest plots in order to identify interdependencies between them and the potential negative effect of soils on development of the forest.

Based on the GIS techniques, raster databases (Fig. 4, 5, 6 and 7) were obtained in digital 


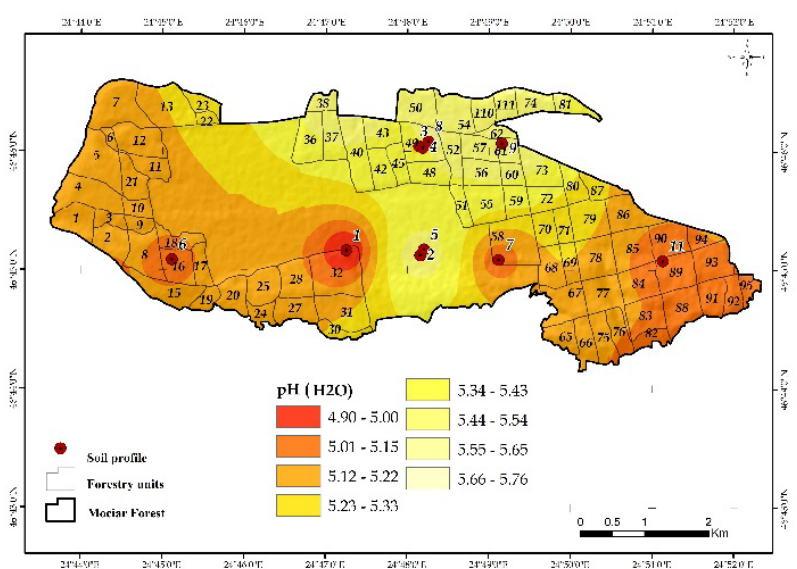

Fig. 4. Variation of soil $\mathrm{pH}$

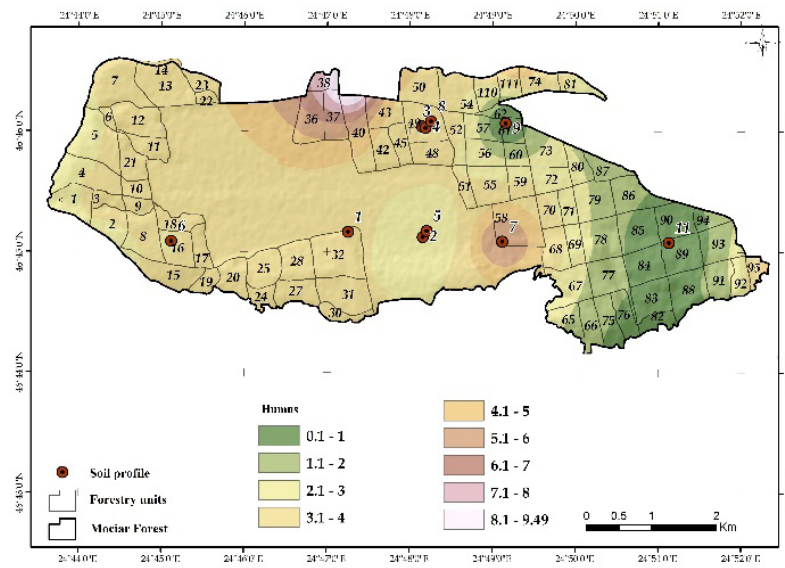

Fig. 6. Variation in total humus

format for all soil characteristics obtained in the laboratory stage. The use of spatial interpolation technique based on the IDW model is best suited for the studied area with a validation rate of $91.3 \%$, compared to the other performed interpolation techniques that have a lower validation rate (in the range of 74.8-80.4).

The interpolated values of the soil $\mathrm{pH}$ show a large variation in the studied area, both spatially and in terms of value, ranging from 4,90-5,76 (Fig. 4). The highest values that highlight the acidity of the soil, which imprint a negative effect on the shrub carpet, are recorded in the western part of the area (U. P. 85-95), production units where there is a visible degradation of the quality of the protected forest species.

From a spatial point of view, the large variation is highlighted by the interpenetration of small $\mathrm{pH}$ values in the central-northern area, representing

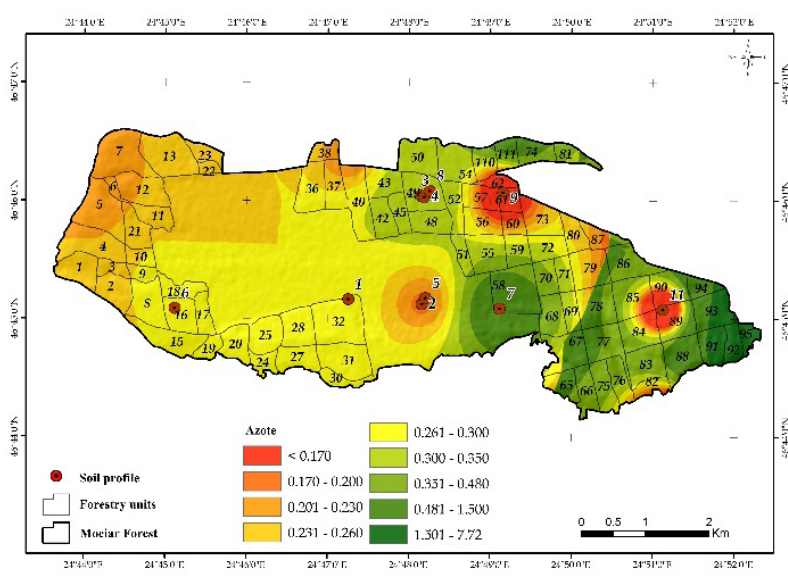

Fig. 5. Variation of nitrogen amount

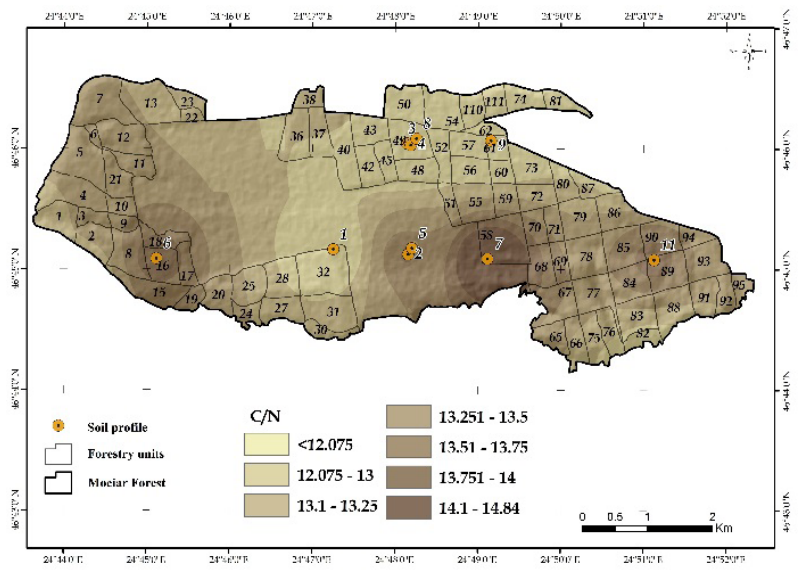

Fig. 7. Variation of $\mathrm{C} / \mathrm{N}$ ratio

a barrier of division of the two extremes analysed, mostly these small values overlapping in territory with the type of use, pasture that acts protectively within the analysed area.

As for the amount of nitrogen, a decrease in the east-west direction with low territorial values in the Northern and Western central sector is observed (Fig. 5). The variation in the total nitrogen content $(\%)$ of the soil varies between $0.170-7.72$, the very high values being identified punctually on the analysed surface.

The interpolated values of soil humus (\%) are in the range of $0.1-9.49 \%$ (Fig. 6), highlighting parcels $36,37,38,40$ with the highest values between 5,1-9.49\%. On the opposite side, the lowest humus quantity is identified on plots 8294, high acidity plots $(\mathrm{pH}<5)$.

The level of transformation of plant resources is highlighted by the $\mathrm{C}: \mathrm{N}$ ratio. In the present 


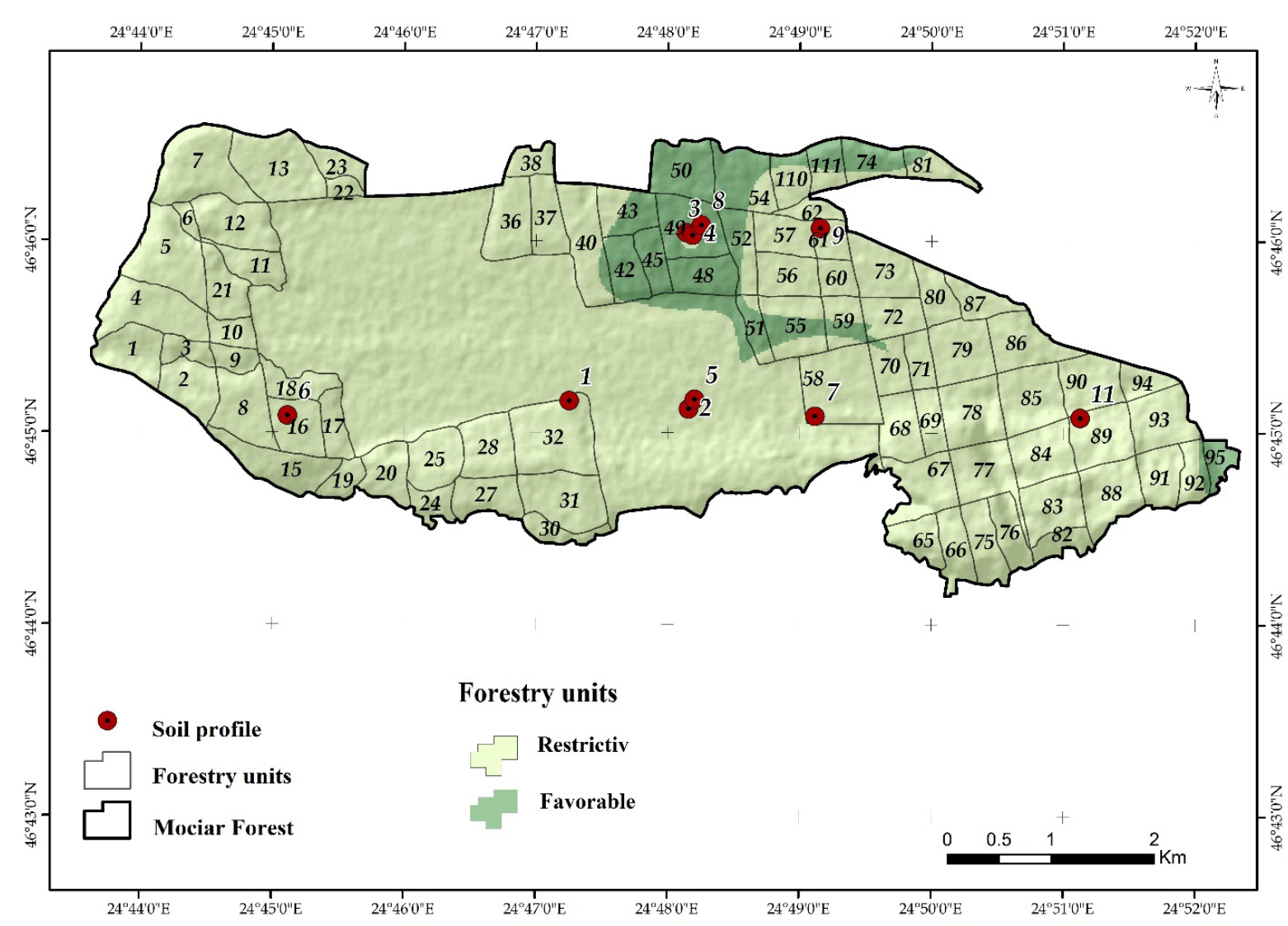

Fig. 8. Map of favorability and soil restriction for forest species in the Mociar forest

analysis, the C: $\mathrm{N}$ parameter is of particular importance because the whole area is within the range of 12, 97-14.84 (Fig. 7), which indicates poor soils in nitrogen, but which by transformation of the vegetable resources increase their production value. At the same time, this range falls within the class of 15 units, which characterizes relatively warm humid regions with grassy vegetation, elements that characterize the studio area and validates the interpolating quality of the point values representing the parameter $\mathrm{C}$ : $\mathrm{N}$.

The identification of stable areas in terms of soil quality and feasible to carry out ameliorative works for the main purpose of improving the current quality of the shrub carpet was made on the basis of the G.I.S. integrating the four analysed indicators in the form of spatial analysis equation.

Parameters taken in the analysis are as follows: $\mathrm{pH} \geq 5$, soil nitrogen $\geq 0.3 \%$, humus quantity $\geq 3 \%$, ratio $\mathrm{C}: \mathrm{N} \leq 13.5$ units. The result of their integration into the spatial analysis is represented by a database that highlights all areas that are valid in terms of the requirements listed above.
The integrated analysis of these parameters highlights two areas that are suitable to the development of forest species, disproportional in terms of surfaces and spatial location on the surface of the analysed area (Fig. 8). The first area and the largest as a spatial extension was identified in the northern central part of the Mociar Forest, overlapping spatially with parcels $42-45,48,49$, 50-51, 74, 111.

The quality of spatial modeling is validated by direct field comparison by the fact that there are 8 experimental plots under parcel 45 monitoring of linden species (Tilia cordata), sycamore (Acer pseudoplatanus), pedunculated oak (Quercus robur), ash tree (Fraxinus excelsior), red oak (Quercus rubra), sânger (Cornus sanguinea), hawthorn (Crataegus monogyna), larch (Larix decidua), chestnut (Castanea sativa) and Californian Cypress (Chamaecyparis lawsoniana), with the main purpose to identify their adaptation to specific environmental conditions and, in particular, to highlight the limiting characteristics of soils. 


\section{CONCLUSION}

The results of this study allow the application of non-invasive measures to decrease soil-induced negative effects on the development of the secular oak forests for which this territory is well known.

GIS techniques of spatial interpolation allow to capture variations in soil parameter values (total humus, $\mathrm{pH}$, soil nitrogen and C: $\mathrm{N}$ ratio) when the analysis is performed on relatively small surfaces and soil profiles are relatively uniformly distributed in within and outside the analysed territory. In the present case, the spatial analysis based on the identification of non-restrictive values for the identification of areas favourable to the existence and development of forest species has successfully been validated, what makes its implementation in similar areas in terms of soil quality to be implemented as long as the analysed areas are not very wide.

Considering the mediocre health condition of the forest, sustained measures are needed to improve the vegetation conditions (possible restoration works of the former ditches and drainage channels), the permanent monitoring of the sanitary condition of the forest and the prompt adoption of measures for combating the negative effects and judicious application of care and management work.

\section{REFERENCES}

1. Anıl CB, Uğur A, Tarık T (2017). Estimating tree heights with images from an unmanned aerial vehicle, Geomatics, Natural Hazards and Risk, 1947-5713, DOI:10.1080/1947 5705.2017.1300608.

2. Asvadurov H (1969). Solurile pădurilor de fag din Nord Vestrul României. Solurile Munţilor Bucegi. Lucrările conferinței naționale de Pedologie, Azuga. Editura Academiei R.S.R., București.

3. Bălăceanu V, Taină Şt, Crăciun C (2002). Solurile brun acide din România. Studiu monographic. Factori şi procese pedogenetice din zona temperate, Vol. 1, editura Universităţii Alexandru Ioan Cuza, Iaşi.

4. Bălănică T, Ceuca G, Chiriță C (1954). Studii privind regenerarea şi refacerea arboretelor de stejar cu fenomene de uscare intensă, 152-288, București.

5. Bui E.N, Smettem KRJ, Moran CJ, Williams J (1995). Use of soil survey information to assess regional salinization risk using Geographical information system. Journal of Environmental Quality, 25(3), 433-439. http://dx.doi. org/10.2134/jeq1996.00472425002500030008x.

6. Campbell JE, Moen JC, Ney RA, Schnoor JL (2008). Comparison of regression coefficient and GIS-based methodologies for regional estimates of forest soil carbon stocks. Environmental Pollution, 152(2), 267-273.
7. Cernescu N (1945). Contribuții la cunoașterea chimismului genetic al solurilor zonale cu orizont de acumulare a argilei. Buletinul Facultăţii de Agronomie, nr. 2, București.

8. Chiriță DC, Păunescu C, Teaci D (1967). Solurile României, Editura Agrosilvică, București.

9. De Veaux RD, Psichogios DC, Ungar LH (1993). A Comparison of two nonparametric estimation schemes: MARS and neural networks. Computers \& Chemical Engineering 17(8): 819-837.

10. El Jamassi A (2013). Using Geographic Information Systems (GIS) in Soil Classification and Analysis in Gaza City, Palestine. Environment and Natural Resources Research, 3(2):146-159.

11. Emerich M, Fuss M (1866). Flora Transilvaniae Exursoriae, inserate în Flora RPR și RSR, volumele I-XII.

12. Florea N (1965). Clasificarea genetico-geografică a solurilor din România, Știința solului, 4, București.

13. Florea N, Munteanu I (2003). Sistemul roman de Taxonomie a solurilor, I.C.P.A., Editura ESTFALIA, Bucureşti.

14. Gherghel M (1983). Unele aspect privind uscare stejarului (Quercus robur) în pădurea Mociar. Ocolul Silvic Valea Gurghiului.

15. Grigoraș C, Boengiu S, Vlăduţ A, Grigoraş EN (2006). Solurile României, Editura Universitaria, Craiova.

16. Gutiérrez A, Contador FL, Schnabel S (2011). Modeling soil properties at a regional scale using GIS and Multivariate Adaptive Regression Splines, Geomorphometry.org.

17. Ianoş Gh (1999). Pedogeografie, Edituta Mirton, Timişoara.

18. Iverson LR, Dale ME, Scott CT, Prasad, A (1997). A GISderived integrated moisture index to predict forest composition and productivity of Ohio forests (USA). Landscape Ecology, 12(5): 331-348.

19. Li X, Lee SL, Wong SC, Shi W, Thornton I (2004). The study of metal contamination in urban soils of Hong Kong using a GIS-based approach. Environmental Pollution, 129(1): 113-124.

20. Lupașcu Gh, Rusu C (1975). Influența reliefului asupra însuşirilor fizico-chimice, hidrofizice şi regimul umidităţii solurilor cernoziomice în zona colinară estică a Depresiunii Cracău-Bistrița (Văleni-Girov), lucrările Staţiunii Stejarul Geologie-Geografie. Pângăraşi.

21. Moore ID, Gessler PE, Nielsen GA, Peterson GA (1993). Soil attribute prediction using terrain analysis. Soil Science Society of America Journal, 57(2): 443-452.

22. Moldovan N, Păcurar I, Bilașco St, Roșca S, Boț AI (2015). Identifying Land Favorability of Intercommunity Association for Development Alba Iulia For Pasture Utilization Through G.I.S. Techniques, Geographia Napocensis, IX(2): 21-28.

23. Muñoz J., Felicísimo ÁM (2004). Comparison of statistical methods commonly used in predictive modelling. Journal of Vegetation Science 15: 285-292.

24. Ollinger SV, Aber JD, Federer A (1998). Estimating regional forest productivity and water yield using an ecosystem model linked to a GIS. Landscape Ecology, 13(5): 323-334. 
25. Păcurar I (2005). Pedologie forestieră, Editura AcademicPress, 88-7, Cluj-Napoca.

26. Păcurar I (2006). Pedologie si statiuni forestiere, Editura RISOPRINT, 450, Cluj Napoca.

27. Paşcovski S (1937). Câteva staţiuni de plante lemnoase din Ardeal, în Analul Institutului de Cercetări şi Experimentaţie forestieră, Vol. 2, București.

28. Paşcovski S (1942). Studii asupra vegetaţiei pădurilor din împrejumuirele Gurghiului, Analele I.C.E.F.

29. Pocovăţ M (1935). Analyse mecanique des sols. Studii tehnice şi economice, Seria C, Ştiinţa solului, nr. 8, Institutul geologic al României, București.

30. Roşca S (2014). Application of soil loss scenarios using the ROMSEM model depending on maximum land use pretability classes. A case study, în Studia UBB Geographia, LIX (pp. 101-116).

31. Roșca S, Bilaşco Şt, Păcurar I, Oncu M, Negruşier C, Petrea D (2015). Land Capability Classification for Crop and Fruit Product Assessment Using GIS Technology. Case Study: The Niraj River Basin (Transylvania Depression, Romania), Not Bot Horti Agrobo, 2015, 43(1):235-242. DOI: $10.15835 /$

32. Roşu C (1982). Stabilirea direcţiilor de evoluţie a principalelor tipuri de staţiuni din regiunea de câmpie și deal și a măsurilor silvotehnice de sporire a productivității acestora", Biblioteca Colegiului Silvic, Gurghiu.

33. Roşu, C (1982). Stabilirea direcţiilor de evoluţie a principalelor tipuri de staţiuni din regiunea de câmpie şi deal şi a măsurilor silvotehnice de sporire a productivităţii acestora". Biblioteca Colegiului Silvic, Gurghiu.
34. Sânmărghitan M (2005). Flora şi Vegetaţia Văii Gurghiului, Biblioteca Colegiului Silvic, Gurghiu

35. Smigaj M, Gaulton R, Barr SL, Suárez JC (2015). Uav-Borne Thermal Imaging for Forest Health Monitoring: Detection of Disease-Induced Canopy Temperature increase, The International Archives of the Photogrammetry, Remote Sensing and Spatial Information Sciences, Volume XL-3/ W3, 349-354.

36. Stăncioiu PT, Lazăr G, Tudoran Gh, Bozga Şt, Predoiu Gh, Şofletea N (2008). Habitate forestiere de interes comunitar incluse în proiectul LIFE05 NAT/RO/000176: „Habitate prioritare alpine, subalpine şi forestiere din România“, Măsuri De Gospodărire, Editura Universității Transilvania din Braşov.

37. Torresan C, Berton A, Carotenuto F, DiGennaro SF, Gioli B, Matese A, Miglietta F, Vagnoli C, Zaldei A, Wallace L (2016). Forestry applications of UAVs in Europe: a review, International Journal of Remote Sensing, 1366-5901, DOI: 10.1080/01431161.2016.1252477.

38. Zhang C, Mcgrath D (2004). Geostatistical and GIS analyses on soil organic carbon concentrations in grassland of southeastern Ireland from two different periods. Geoderma, 119.3: 261-275.

39. Zhu AX, Hudson B, Burt J, Lubich K, Simonson D (2001). Soil mapping using GIS, expert knowledge, and fuzzy logic. Soil Science Society of America Journal, 65(5): 1463-1472.

40. ***, I.C.P.A., 1987, Metodologia elaborării studiilor pedologice (vol. I), Bucureşti. 